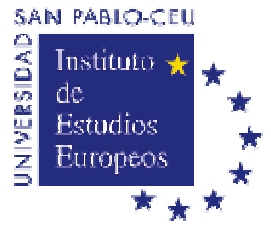

Polo EUROPEO JeAn MONNET

JeAN MONNET EUROPEAN CENTRE OF EXCELLENCE

\title{
ON CAPITAL STRUCTURE \\ IN THE SMALL AND MEDIUM ENTERPRISES: THE SPANISH CASE
}

\author{
Francisco Sogorb Mira
}

$N^{\circ} 2-2002$

\author{
D. FRANCISCO SOGORB MIRA
}

FACULTAD DE CIENCIAS SOCIALES, JURÍDICAS Y DE LA COMUNICACIÓN

Universidad Cardenal HeRrera- CEU 
El Instituto de Estudios Europeos de la Universidad San Pablo-CEU, Polo europeo Jean Monnet, es un Centro de investigación especializado en temas europeos cuyo objetivo es contribuir a un mayor conocimiento y divulgación de los temas relacionados con la Unión Europea.

Los Documentos de Trabajo dan a conocer los proyectos de investigación originales realizados por los investigadores asociados del Instituto Universitario en los ámbitos histórico-cultural, jurídico-político y socioeconómico de la Unión Europea.

El Observatorio de Economía Europea es una iniciativa conjunta del Instituto de Estudios Europeos y de la Facultad de Ciencias Económicas y Empresariales de la Universidad San Pablo-CEU cuya finalidad es la creación de un foro de estudio y reflexión sobre la economía europea.

El Observatorio de Economía Europea publica en su Colección de Informes análisis de la situación y evolución de las cuestiones económicas y sociales relacionadas con la Unión Europea.

Serie de Colección de Informes del Observatorio de Economía Europea del Instituto de Estudios Europeos.

"On capital structure in the Small and Medium Enterprises: the Spanish case"

No está permitida la reproducción total o parcial de este trabajo, ni su tratamiento informático, ni la transmisión de ninguna forma o por cualquier medio, ya sea electrónico, mecánico, por fotocopia, por registro u otros métodos, sin el permiso previo y por escrito de los titulares del copyright.

Derechos Reservados (c) 2002, por Francisco Sogorb Mira.

Derechos Reservados (C) 2002, por Instituto de Estudios Europeos de la Universidad San Pablo-CEU.

C/ Julián Romea, 22

28003 Madrid

e-mail: idee@ceu.es

URL: hHtp://www.ceu.es/idee.htm

ISBN: 84-95219-49-2

Depósito legal: M-24580-2002

Diseño de cubierta: Encarnación Navarro.

Compuesto e impreso en Docutech. 


\title{
ON CAPITAL STRUCTURE IN THE SMALL AND MEDIUM ENTERPRISES: THE SPANISH CASE
}

\author{
FRANCISCO SOGORB MIRA'
}

\begin{abstract}
The principal aim of this paper is to test the relevance of the different financing theories for explaining capital structure choice in the Small and Medium Enterprises (SMEs) sector. We carry out an empirical analysis over a panel data of 3962 non financial Spanish SMEs. Our results show that the financing decision in these companies could be explained by the main capital structure theories: Fiscal Theory, Trade - Off Theory and Pecking Order Theory. Among all these theories, some caveats are worth to be stressed and the hierarchically theory seems to fit completely in the explanation of SMEs debt policy.

Keywords: Financing, Capital Structure, Trade - Off Theory, Pecking Order Theory, SME, Panel Data.

JEL Classification: C23, G32, G33.
\end{abstract}

\footnotetext{
' I would like to express my gratitude to J. Carlos Gómez for his inestimable help and encouragement, and to Manuel Arellano, Antonio Falcó, José López and Javier Suárez for their invaluable comments on earlier drafts. All the errors are of my own entire responsibility.
} 


\section{ÍNDICE}

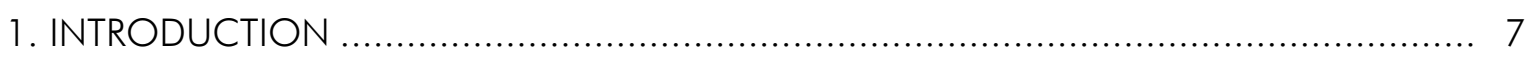

2. THEORETICAL DISCUSSION AND EMPIRICAL HYPOTHESE ................................... 8

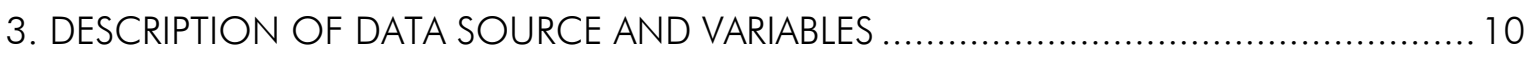

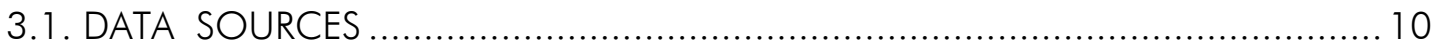

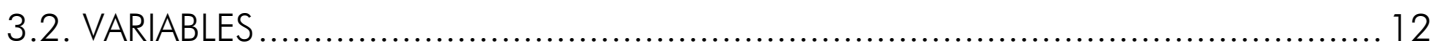

4. ECONOMETRIC METHODOLOGY AND EMPIRICAL RESULTS................................. 14

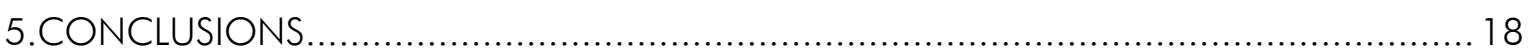

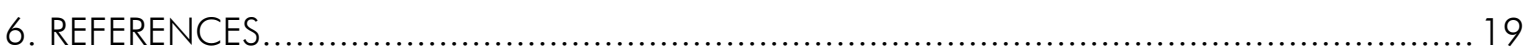




\section{INTRODUCTION}

It is a real and clear fact that small and medium enterprises, hereinafter SMEs, represent a vast portion of the firm tissue of almost every developed country. In this respect, the fourth report about European companies carried out by the European Commission (1996), reveals that the total number of firms existing in the European Union in 1992 mounted up to 15777000 , from which $99.8 \%$ were considered SMEs. Moreover, these SMEs provided approximately around $66 \%$ of European employment and $65 \%$ of European companies turnover.

All these figures show the great importance of this category of firms, but not always receiving the joust attention that they really deserve. In words of Zingales (2000, p. 1629): "Empirically, the emphasis on large companies has led us to ignore (or study less than necessary) the rest of the universe: the young and small firms, who do not have access to public markets".

One of the areas of financial theory that has worried much to academicians and professionals is debt policy decisions in companies. Although there are many previous empirical studies about financing decisions of large and listed companies ${ }^{2}$, the scientific community has only started to pay attention to the small firm sector much more recently.

In spite of this, we now have available a considerable number of empirical works worldwide like Constand et. al (1989), Van der Wijst (1989), Walker (1989a,b), Holmes and Kent (1991), Van der Wijst and Thurik (1993), Chittenden et al. (1996), Calcagnini and lacobucci (1997), Hamilton and Fox (1998), Jordan et al. (1998) and Michaelas et al. (1999), and also for the Spanish context like Calvo and Lorenzo (1993), Ocaña et. al (1994), Sáez (1996), Maroto (1996), Boedo and Calvo (1997), Aybar et al. (1999), Aybar et al. (2000) and López and Aybar (2000).

Following this line of research, we aim to obtain the determinants of debt policy decisions in small firms. Specifically, we investigate whether and to what extent the main capital structure theories can explain financing decisions of small and medium enterprises. To achieve this goal we use a panel data methodology controlling for individual heterogeneity, and a more complete and bigger sample than the foregoing studies.

The structure of the remainder of the paper is as follows. Section 2 studies how the existing capital structure theories can be used to explain the financing decisions in the small business sector, and at the same time we present the empirical hypotheses extracted from the theoretical background that will be tested over a Spanish small and medium enterprise sample. Section 3 explains in detail all the variables used in the study; besides it describes how we have constructed the firm sample. The model employed as well as the econometric techniques that we have applied, are discussed in section 4. Also in this section we show the empirical results of the study with their implications. Finally, we conclude in section 5 where we also include some proposals for the future line of research in this area.

\footnotetext{
2 For example, Bradley et al. (1984), Auberbach (1985), Friend and Hasbrouck (1988), Titman and Wessels (1988), Barclay et al. (1995), Rajan and Zingales (1995), Graham (1996), Chen et al. (1998), Shyam Sunder and Myers (1999), Wald (1999), Wiwattanakantang (1999) and Hovakimian et al. (2001).
} 


\section{THEORETICAL DISCUSSION AND EMPIRICAL HYPOTHESES}

The seminal work of Modigliani and Miller (1958) set up the basis for the development of a theoretical body around the firm capital structure issue. Its main proposition establish that the valuation of a company will be independent from its financial structure. As this conclusion is absolutely true under the assumptions Modigliani and Miller (1958) took into account ${ }^{3}$, the enlargement of the theory onwards has been produced relaxing these fundamental assumptions, also with the aim of approximating the theory to the firm reality.

From this point of view, we categorize capital structure theory under 3 stances, depending on which economic aspect we focus on.

First of all, we can mention capital structure FISCAL THEORY (FT). Modigliani and Miller corrected their original paper in 1963, and concluded that firms would prefer debt to other financing resources due to the tax deductibility of interest payments. Therefore, one of our fiscal theory hypothesis will be,

\section{HYPOTHESIS / (FT): "The effective tax rate should be positively related with debt"}

Some authors like Pettit and Singer (1985) have pointed out that fiscal theory can not be applied in the small firm context, because SMEs are less likely to be profitable and therefore to use debt in order to get tax shields. Following this line of reasoning the foregoing hypothesis could be established as "there should not exist any relation between debt and taxes in SMEs" ${ }^{5}$

On the other hand, DeAngelo and Masulis (1.980) show that there are other alternative tax shields such as depreciation, research and development expenses, investment deductions, etc., that could substitute the fiscal role of debt. Our second fiscal theory hypothesis will be:

HYPOTHESIS // (FT): "Non - debt tax shields ought to be negatively correlated with leverage"

In second place, we consider capital structure TRADE - OFF THEORY (TOT) where we include not only the advantages of debt employment as a mode of financing but also its shortcomings from a financial distress and agency theory viewpoints.

As Warner (1977), Smith and Warner (1979), Ang et al. (1982) and Pettit and Singer (1985) point out, larger firms tend to be more diversified and fail less often, so size can be an inverse proxy for the probability of bankruptcy ${ }^{6}$. Besides, small companies use to have bigger bankruptcy costs in relative terms ${ }^{7}$. Under this assertions, we can construct our first trade - off theory hypothesis in the following manner:

HYPOTHESIS III (TOT): "Firm Size should be positively correlated with debt level"

\footnotetext{
3 Namely, perfect capital markets, no taxes, absence of agency and transactions costs and independence between the productive activity of the firm and the way it is financed.

${ }^{4}$ Tax rate hypothesis from Scott (1976) and hypothesis 5 from DeAngelo and Masulis (1980).

${ }^{5}$ Graham (1996) find a positive relation between firm size and taxes, which implies that SMEs have lower tax rates.

${ }^{6}$ Note however, as Rajan and Zingales (1995) state, that size may also be a proxy for the information outside investors have, which should increase their preference for equity relative to debt.

${ }^{7}$ See Warner (1977) and Ang et al. (1982).
} 
Agency theory investigates the conflicts of interests between the various financial stakeholders of the firm. Basically, this theory considers the conflicts of interest brought about on the one hand between shareholders and creditors, and on the other hand between shareholders and managers. SMEs are not likely to suffer from this second problem due to the fact that their property identifies almost exactly with their management and thereby there will only be a unique financial objective for these two groups. Notwithstanding, the agency conflict between shareholders and lenders may be particularly severe for small companies ${ }^{8}$.

As Myers (1977) states, the underinvestment problem becomes more intense in companies with more growth opportunities, and this fact will take creditors to reduce their supply of funds to this type of firms. One of the possible solutions to mitigate this problem could be the employment of short term debt by the firm. In theory, and according to Myers' assertion, there should be a negative relationship between debt and growth opportunities, however some authors like Michaelas et al. (1999) have propounded a positive correlation between these two variables because SMEs mainly use short term debt financing. In line with this last proposition, our second trade - off theory hypothesis is:

HYPOTHESIS IV (TOT): "Growth opportunities ought to be positively related with firm leverage"

Which could be decomposed into:

HYPOTHESIS IV-a (TOT): "Long term debt should be negatively correlated with growth opportunities"

HYPOTHESIS IV-b (TOT): "Short term debt should have a positive correlation with growth opportunities ${ }^{91}$

The restriction of maturity length in the credit offered by lenders may explain in part debt structure in SMEs. In this sense, small firms may use less long term debt, but probably more short term debt, than larger firms. This may suggest, following Bevan and Danbolt (2000b), these next relationships in form of our third trade - off theory double hypothesis:

HYPOTHESIS V-a (TOT): "Long term debt should be positively correlated with firm size"

HYPOTHESIS V-b (TOT): "Short term debt should have a negative correlation with firm size"

The existence of debt agency costs like risk shifting, and potential problems of adverse selection and moral hazard, may induce creditors to require guarantees to their lending, materialized in collateral assets ${ }^{10}$. This type of assets will retain value in case of a potential liquidation of the firm, and could be sold in the market to face the firm's payment commitments. We formulate our fourth and last trade - off theory hypothesis in the following terms:

\footnotetext{
${ }^{8}$ Van der Wijst (1989) and Ang (1992).

${ }^{9}$ According to Barclay and Smith (1999), when firms with high growth opportunities use debt financing, they will prefer short term debt or debt with few restrictive covenants instead of long term debt, in order to maintain their financial flexibility.

10 See Myers (1977), Scott (1977) and Harris and Raviv (1990).
} 
HYPOTHESIS VI (TOT): "The firm leverage ratio should relate positively to asset tangibility"

According to the maturity matching principle from Brealey and Myers (2000), the preceding hypothesis could be enlarged in the following sense:

HYPOTHESIS VI-a (TOT): "If firms aim to match maturities of assets and liabilities, we should observe a positive correlation between fixed assets ratio and long term debt ratio, while it would be negative if leverage ratio were short term"

If we consider the existence of informational asymmetries between investors and managers, two additional capital structure theories appear: the SIGNALING THEORY (ST) and the PECKING ORDER THEORY (POT). The former theory is of little use for the small firm sector as SMEs are not usually listed in stock exchange markets and therefore their managers do not intend to signal something to the market and investors while adopting their financing decisions. On the contrary, the latter theory could be very useful for our purposes.

Myers (1984) and Myers and Majluf (1984) argue that it exists a hierarchy in the financing funds of companies. Due to informational asymmetries, firms will prefer internal to external capital sources. This suggests that high profitable companies will tend to finance investments with retained earnings rather than using debt. It is worthy stressing that this way of firm financing could easily be applied to SMEs through the following reasoning: SMEs managers, that are usually at the same time shareholders of this companies, do not like to lose their property and control over these firms ${ }^{11}$, and therefore the acceptance of new shareholders will be almost insignificant, preferring internal financing to external resources to finance firm activity ${ }^{12}$. In case SMEs needed external funds, they would choose debt that does not reduce managers' operability, that is short term debt which is not likely to include restrictive covenants. Under this last theoretical stance, we propose these two hypotheses:

HYPOTHESIS VII (POT): "There should be a negative relation between leverage and firm profitability"

HYPOTHESIS VIII (POT): "SMEs employ predominantly short term debt as debt financing"

\section{DESCRIPTION OF DATA SOURCE AND VARIABLES}

\subsection{Data source}

A key question in all SMEs literature is the definition of what is really considered as a small business. Every author, in most of the cases, has defined this sort of business quite differently. For instance, Van der Wijst (1989) considers small and medium - sized business as privately held firms with $1-9$ and $10-99$ people employed, respectively; Ocaña et al. (1994) investigate firms with less than 50 employees (small) and firms with employees

\footnotetext{
${ }^{11}$ Holmes and Kent (1991) and Hamilton and Fox (1998).

12 In his revised version of the pecking order theory applied to SMEs, Ang (1991) establishes that the second financing resource for SMEs, after retained profits, will be funds supplied by the present firm shareholders.
} 
between 50 and 200 (medium); Boedo and Calvo (1997) work with firms that have a 2.4 3.6 million $€$ turnover; Jordan et al (1998) define SMEs as firms with less than 100 employees and less than 15 million $€$ turnover; Michaelas et al. (1.999) consider small independent private limited companies with less than 200 employees; López and Aybar (2000) analyze companies with sales below 15 million $€$; and Aybar et al. (2000) contemplate firms with sales under 2.4 million $€$ (small) and firms with sales between 2.4 million $€$ and 15 million $€$ (medium). This fact suggests that there is not a general consensus over what a small business is.

Instead of taking any of the previous criterions, we have adopted the European Commission SME definition ${ }^{13}$ : companies with less than 250 employees, sales below 40 millions $€$, total assets under 27 millions $€$ and independent privately held ${ }^{14}$.

The sample of SMEs considered in our study has been extracted from SABE (Sistema de Análisis de Balances Españoles), which is a database that contains economic and financial information with up to eight years of history over more than 190000 Spanish firms.

Specifically, we have selected those firms from this database that meet the following requirements:

- Less than 250 employees.

- Less than 40 million $€$ turnover.

- Less than 27 million $€$ total assets.

- Positive equity resources (shareholders' equity) and also positive net income over the whole period of study.

- Not included in a bankruptcy process.

The data set has been restricted to observations that embody all the essential variables available, and also these variables have a complete record over the period of examination.

The definitive number of firms that makes up our sample amounts to 3962, for which we have accounting data for the five year period time $1994-1998^{15}$, resulting in a 19810 observations balanced panel data. It should be noted that our firm data panel is much more complete that the ones that have been used in previous studies, and enjoys a greater number of observations ${ }^{16}$.

The vast majority of empirical studies about firm capital structure usually consider companies from mixed industries. However, almost all of them regularly exclude from their analysis firms belonging to the insurance and financial industry because of their specific

\footnotetext{
${ }^{13}$ Recommendation 96/280/EC, April 3, 1996.

${ }^{14}$ These firms can not belong to a big company or to a group of companies.

${ }^{15}$ As the SABE database was created in 1992, its firsts two years of performance are not very complete in terms of firm data, so we preferred to begin our study from 1994 onwards in order to use a greater quantity and a better quality information.

16 For instance, López and Aybar (2000) consider only 445 SMEs with 1 year (1995) of observations and although Michaelas et al. (1999) analyze about 3500 SMEs over a 10 year period, they do not have at their disposal firm information for the whole period of time, taking into account less than 2000 companies for some of the years of study.
} 
financial behavior and particular nature ${ }^{17}$. Moreover, if we attempt to analyze the financing decision in SME, it would be nonsense to include the cited industries in our study.

Firm distribution by industries of our sample and the specific weight of each firm sector over the total sample is shown in the following table:

\section{Table 1: Firm distribution by industries and specific weights}

\begin{tabular}{|l|c|c|}
\hline \multicolumn{1}{|c|}{ Industry } & Number of firms & \% of total firms \\
\hline Agriculture, forestry and mining & 549 & 11.776 \\
\hline Manufacturing & 1117 & 23.960 \\
\hline Construction & 380 & 8.151 \\
\hline Wholesale and retail trade & 1713 & 36.744 \\
\hline Hotels and restaurants & 134 & 2.874 \\
\hline Transport and communications & 231 & 4.955 \\
\hline Business services & 410 & 8.795 \\
\hline Education, health and social work & 49 & 1.051 \\
\hline Other & 79 & 1.695 \\
\hline
\end{tabular}

Both manufacturing and wholesale and retail trade prevail over the rest of industries, denoting the industrial character of the sample.

\subsection{Variables}

In each of the empirical hypotheses that we formulated in section 2 an economic or financial aspect of the firm was taken into account, and the question that arises now is how to measure these attributes. Capital structure theory does not specify clearly this issue, which has taken some researchers like Titman and Wessels (1988) or Harris and Raviv (1991) to conclude that the choice of appropriate both dependent and explanatory variables is potentially controversial. Nonetheless, previous empirical work can help us to define objectively the proxy variables needed to take on our study.

The variable that we intend to explain is SME capital structure, which we measure by total debt ratio (TDR): $\frac{\text { Total Debt }}{\text { Total Assets }}$.

But as argued by Van de Wiist and Thurik (1993), Chittenden et al. (1996), Barclay and Smith (1999) and Bevan and Danbolt (2000a), any analysis of leverage determinants based only on total liabilities may screen the important differences between long - term and short - term debt. Consequently, in order to shed some light over this question and to get a better understanding of capital structure and its determinants, we also consider the following two measures of leverage:

\footnotetext{
17 See, for example, Rajan and Zingales (1995), Graham (1996), Chen et al. (1998), López et al. (1999); Wald (1999); Wiwattanakantang (1999); Shyam - Sunder and Myers (1999); Bevan and Danbolt (2000a); Bevan and Danbolt (2000b).
} 
- Long term debt ratio (LDR): $\frac{\text { Long Term Debt }}{\text { Total Assets }}$

- Short term debt ratio (SDR): $\frac{\text { Short Term Debt }}{\text { Total Assets }}$

As far as explanatory variables is concerned, we have selected several proxies that have been most used in the empirical literature.

- Effective Tax Rate (ETR): $\frac{\text { Taxes }}{\text { EAIBT+Depreciation }}$

where EAIBT denotes Earnings after interest and before taxes

- Non - Debt Tax Shields (NDTS): $\frac{\text { Depreciation }}{\text { Total Assests }}$

- Growth Opportunities (GO): $\frac{\text { Intangible Assets }}{\text { Total Assests }}$

- Asset Structure (AS): $\frac{\text { Tangible Assets }}{\text { Total Assets }}$

- Size (S): Natural logarithm of total assets

- Profitability $(\mathrm{P}): \mathrm{ROA}=\frac{\mathrm{EBIT}}{\text { Total Assets }}$

where EBIT denotes Earnings Before Interest and Taxes

A preliminary study of our data sample provides us with the main descriptive statistics of both dependent and explanatory variables that we collect in table 2 .

Table 2: Descriptive statistics of dependent and explanatory variables

\begin{tabular}{|c|c|c|c|c|c|}
\hline Variable & Obs. & Mean & Std. Deviation & Minimum & Maximum \\
\hline TDR & 19810 & 0.5602 & 0.2244 & 0 & 0.9919 \\
\hline LDR & 19810 & 0.0828 & 0.1282 & 0 & 0.911 \\
\hline SDR & 19810 & 0.4774 & 0.2201 & 0 & 0.9919 \\
\hline ETR & 19810 & 0.1863 & 0.1069 & 0 & 0.8789 \\
\hline NDTS & 19810 & 0.036 & 0.0374 & 0 & 0.8088 \\
\hline GO & 19810 & 0.0329 & 0.07 & 0 & 0.9386 \\
\hline AS & 19805 & 0.4354 & 0.2347 & 0 & 1 \\
\hline S & 19810 & 14.3847 & 1.0901 & 8.1685 & 17.111 \\
\hline P & 19810 & 0.0937 & 0.0909 & -1.5213 & 3.5468 \\
\hline
\end{tabular}


A quick review to table 2 displays several issues. In first place, total liabilities on average amount to about $56 \%$ of total assets value. If we split total liabilities into fixed liabilities (repayable in more than one year) and current liabilities (repayable in less than one year), the figures $8 \%$ and $48 \%$ respectively, show that debt financing for SMEs in our sample corresponds mainly to a short term nature, exactly $86 \%$. This fact is consistent with our empirical hypothesis IX.

The average effective tax rate of Spanish SMEs is almost 19\%, which is clearly lower than the general tax rate that moves between 30\% and 35\% in Spanish fiscal system, depending basically on the economic situation of companies.

With respect to asset structure, we find that intangible assets represent over $3 \%$ of total assets value, whereas fixed assets represent about $44 \%$ of total assets.

The mean of the natural logarithm of total assets over the period 1994 - 1998 indicates that the average size of SMEs was approximately $1766834 €$ in terms of assets, ranging from a $3528 €$ minimum value to a $26990621 €$ maximum value.

As far as profitability is concerned, the average return on assets over the period of study mounts up to almost 10\%, finding a great disparity between firms, with a $-152 \%$ minimum value to a $355 \%$ maximum value.

To examine the possible degree of collinearity among variables, we have obtained the correlation matrix of dependent and independent variables that we gather in table 3.

Table 3: Correlation Matrix

\begin{tabular}{|c|c|c|c|c|c|c|c|c|c|}
\hline & TDR & LDR & SDR & ETR & NDTS & GO & AS & S & P \\
\hline TDR & 1 & & & & & & & & \\
\hline LDR & 0.3187 & 1 & & & & & & & \\
\hline SDR & 0.8338 & -0.2575 & 1 & & & & & & \\
\hline ETR & -0.1721 & -0.1929 & -0.0631 & 1 & & & & & \\
\hline NDTS & -0.1133 & 0.1296 & -0.191 & -0.391 & 1 & & & & \\
\hline GO & 0.1144 & 0.2706 & -0.041 & -0.1505 & 0.2626 & 1 & & & \\
\hline AS & 0.0147 & 0.2596 & -0.1362 & -0.2169 & 0.1111 & -0.1595 & 1 & & \\
\hline S & 0.0246 & 0.072 & -0.0169 & 0.0974 & -0.0458 & -0.0276 & 0.0527 & 1 & \\
\hline P & -0.1374 & -0.260 & -0.125 & 0.2697 & 0.0287 & 0.0211 & -0.1053 & -0.017 & 1 \\
\hline
\end{tabular}

As we observe in this table, the correlation coefficients are not sufficiently large to cause collinearity problems in the regressions.

\section{ECONOMETRIC METHODOLOGY AND EMPIRICAL RESULTS}

The panel character of our data allows us to use a panel data methodology for our empirical research. As Baltagi (1995) states this type of analysis presents clear advantages over cross sectional or time series studies. For instance, it can control for firm 
heterogeneity, and reduce collinearity among the variables that are contemplated ${ }^{18}$. Besides, this technique enables us to eliminate the potential biases in the resulting estimates due to correlation between unobservable individual effects and the explanatory variables included in the study.

Our panel data model may be represented as follows:

$$
y_{i t}=X_{i t}^{\prime} \cdot \beta+\eta_{i}+u_{i t}
$$

where $Y$ is the dependent variable, $X$ is a $6 \times 19810$ vector that contains all the explanatory variables, $\beta$ is also a $6 \times 19810$ vector with the variable coefficients that we pretend to estimate, $\eta_{i}$ denotes the unobservable individual specific effect that is time invariant $^{19}$, and $\boldsymbol{U}_{i t}$ is the random error, with i denoting firms (cross - section dimension) ranging from 1 to 3962 and t denoting years (time -series dimension) ranging from 1 to 5 .

A critical question in cross section models is to identify whether the unobservable individual effects are fixed or random, that is if these effects are orthogonal or not to the exogenous variables considered. Usually, the individual effects are correlated with the independent variables, and as Mato (1990) asserts, this generates biases in the least squares estimators. Notwithstanding, one of the main advantages of panel data models, as the one we employ in this work, is that they give us the possibility to eliminate the cited biases $^{20}$.

To verify the character of the individual effects, it is usually employed the Hausman's (1978) specification test over the null hypothesis that the individual effects are not correlated with the independent variables $\left[\mathrm{H}_{0}: \operatorname{Cov}\left(\eta_{i}, X_{i t}\right)=0\right]$. If we accept the null hypothesis, the individual effects are supposed to be random and we will have to apply Generalized Least Squares (GLS) to our model with instrumental variable estimators. However, if we find that $\mathrm{H}_{0}$ is false, the individual effects are fixed and the GLS estimator becomes biased and inconsistent. In this latter case we will have to transform our original model, subtracting the average of the variables from it:

$$
y_{i t}-\bar{y}_{i}=\left(X_{i t}^{\prime}-\bar{X}_{i}\right) \cdot \beta+\left(u_{i t}-\bar{u}_{i}\right)
$$

This new model is called the within group transformation, and we can use Ordinary Least Squares (OLS) to estimate its parameters, which will provide unbiased estimators.

The outcome of the Hausman's specification test in our study ${ }^{21}$ enables us to reject the hypothesis regarding the absence of correlation between the individual unobservable effects and the explanatory variables and, thereby, the choice should be the fixed effects and the within transformation model. It should be pointed out that some authors, like Michaelas et al. (1999) have based their fixed - random choice upon a more intuitive

\footnotetext{
${ }^{18}$ Arellano and Bover (1990).

19 In our study we could associate to this effect the unobservable entrepreneurial or managerial skills of the firm's executives.

${ }^{20}$ Baltagi, 1995.

${ }^{21}$ The test statistics for the model with TDR, LTD and STD as dependent variables are 1071.69, 347.94, and 497.14, respectively. All these statistics are asymptotically $\chi^{2}$ distributed with 6 degrees of freedom, and have a p-value of 0.0000 .
} 
reasoning, rejecting one of the options only whether the sample was supposed to represent the whole economy of a country. However, there is no economical nor econometrical reason to consider a priori one of the cited effects. Therefore, if we do not apply this testing methodology we could lose statistical efficiency in the estimation stage.

Once we carry out the regression analysis, we find the following empirical results that are reported in table 4.

Table 4: Regression results

\begin{tabular}{|c|c|c|c|}
\hline & TDR & LTD & STD \\
\hline \multirow{2}{*}{ Constant } & -0.5583 & -0.5612 & $0.003^{*}$ \\
& $(-16.73)$ & $(-19.333)$ & $(0.08)$ \\
\hline \multirow{2}{*}{ ETR (FT) } & -0.1551 & -0.0987 & -0.0564 \\
& $(-15.053)$ & $(-11.011)$ & $(-4.929)$ \\
\hline \multirow{2}{*}{ NDTS (FT) } & -0.6169 & -0.2403 & -0.3766 \\
& $(-16.899)$ & $(-7.567)$ & $(-9.288)$ \\
\hline \multirow{2}{*}{ S (TOT) } & 0.0802 & 0.0426 & 0.0376 \\
& $(34.909)$ & $(21.33)$ & $(14.723)$ \\
\hline \multirow{2}{*}{ GO (TOT) } & 0.1597 & 0.4165 & -0.2568 \\
& $(9.625)$ & $(28.852)$ & $(-13.935)$ \\
\hline \multirow{2}{*}{ AS (TOT) } & 0.0376 & 0.1052 & -0.0676 \\
& $(5.377)$ & $(17.292)$ & $(-8.705)$ \\
\hline \multirow{2}{*}{ P (POT) } & -0.0684 & -0.0427 & -0.0467 \\
& $(-5.808)$ & $(-2.119)$ & $(-3.57)$ \\
\hline R & 0.1145 & 0.0993 & 0.035 \\
\hline F & 341.22 & 290.96 & 95.73 \\
& {$[p-v a l u e: 0.0000]$} & {$[p-v a l u e: 0.0000]$} & {$[p-v a l u e: 0.0000]$} \\
\hline Number of & 19805 & 19805 & 19805 \\
\hline observations & & & \\
\hline
\end{tabular}

t-statistics in brackets; ${ }^{*}$ denotes not statistically significant.

A general outlook to the results illustrates that all the correlations between variables are highly statistically significant, besides the F joint test underlines the need of considering all the variables from an statistical viewpoint.

The two proxy variables that have to do with capital structure Fiscal Theory show mixed evidence. On the one hand, the effective tax rate appears to have a significant negative relation with firm leverage which indicates that hypothesis I is rejected. One of the possible explanations of the sign of this effect could be reverse causation between taxes and the firm leverage variable. In this case, companies with more debt level would pay lesser taxes. But perhaps, alternatively, SMEs managers do not try to reduce their fiscal commitment through debt, because they employ other devices to achieve this goal like the ones included in hypothesis II.

Michaelas et al. (1999) obtain this same sign in the relation, although theirs turn out to be not statistically significant to a $5 \%$ confidence level. Jordan et al (1998) also find a negative relationship, explained by the fact that taxes influence debt only due to the effect over retained earnings. 
On the other hand, alternative tax shields seem to be negatively related with debt. This fact provides empirical support for hypothesis II, that is obviously accepted, and shows evidence for the controversial DeAngelo and Masulis (1980) hypothesis in the small firm sector.

As revealed in table 4, size is positively related to debt, which suggests that this variable determines firm leverage not only for larger firms but also among SMEs. Hypothesis III is thus accepted.

Regarding the decompositional analysis of debt, we observe positive relationships between size and both long term debt and short term debt. Larger firms seem to employ more debt independently of its expiration, because they can hold a greater bargaining power towards creditors. In this case, hypothesis $V-a$ is accepted but hypothesis $V-b$ is rejected ${ }^{22}$.

SMEs with more growth opportunities include more debt in their capital structures which takes us to accept hypothesis IV ${ }^{23}$. Nevertheless, a significant negative correlation appears between the ratio of intangible assets over total assets and short term debt, which may evidence the different time nature of this sort of assets and liabilities, taking us to reject hypotheses IV-a and IV b.

As was hypothesized, we find that asset structure is positively related to firm total leverage and so we accept hypothesis VI. Remember that SMEs are more likely to suffer from moral hazard and adverse selection problems, therefore the collateral value of their assets could help to reduce this sort of problems.

As can be seen from table 4, the correlation between leverage and asset structure changes significantly depending on the type of leverage ratio it is used. Specifically, we find that long term debt ratio is positively correlated with asset structure, while this correlation becomes negative if we consider short term debt ratio. The same result is obtained by Van der Wijst (1989), Van der Wijst and Thurik (1993), Chittenden et al. (1996), Van der Wijst (1997) and Aybar et al. (1999).

The asset structure variable measures the ratio of tangible to total assets, made up mainly by fixed assets which tend to be long term in nature. The negative correlation between asset structure and short term debt ratio ${ }^{24}$ means that short term debt (current liabilities) is used to finance non - fixed assets, consisting basically current assets. This is the so - called maturity matching principle from Brealey and Myers (2000), which was reflected in hypothesis VI-a that we clearly accept.

Finally, the negative coefficient on profitability implies evidence for the pecking order theory, where more profitable SMEs tend to use lesser debt when financing their activity. Hypothesis VII is accepted and SMEs prefer internal resources to external ones as mode of financing.

\footnotetext{
22 Bevan and Danbolt (2000b) get similar results, and they only accept our hypothesis V-b for bank debt.

${ }^{23}$ Aybar et al. (1999) and Michaelas et al. (1999), obtain a significant positive relationship between growth opportunities and debt, the same as Chittenden et al. (1996) and Jordan et al. (1998), although these latter not statistically significant.

${ }^{24}$ Bevan and Danbolt (2000a) find a negative and significant correlation between tangibility and gearing, when the latter is defined as non - equity liabilities (total debt plus trade credit and equivalent) to total assets.
} 


\section{CONCLUSIONS}

Some researchers have pointed out that financial policy in SMEs can be explained by the most known capital structure theories. In order to shed some light over this question and to get a more thorough understanding of the underlying forces that drive capital structure decisions in the SME sector, in this paper we have tested some empirical hypotheses, based on different financing decision theories, over a panel of 3962 non financial Spanish small and medium enterprises during the period $1994-1998$. The three main capital structure theories considered are Fiscal Theory, Trade - Off Theory and Pecking Order Theory.

We both confirm some prior findings using an alternative more complete data set and extend the analysis using additional firm characteristics such as nondebt tax shields, and a decompositional analysis of firm leverage.

In Fiscal Theory, we find leverage to be significantly negatively correlated with alternative tax shields like depreciation, which may seem to confirm DeAngelo and Masulis (1980) theory when we apply it to SMEs. Contrary to expectations, we observe that taxes are negatively related to debt.

On the other hand, Trade - Off Theory, allows us to extend the explanation in part of the financial behavior of SMEs. First of all, size and asset structure are both positively correlated with firm debt level, as stated by the theory. However, regarding asset structure we obtain a positive correlation with long term debt level but negative with short term debt level. This may evidence the maturity matching principle in SMEs, where they try to finance their fixed assets with long term debt, and their current assets with short term debt.

Secondly, SMEs with more growth options seem to employ more debt, although this relationship becomes negative with short term debt. This fact may suggest that this kind of assets are linked to a long term nature, and thus their financing should match it.

Finally, Pecking Order Theory seems to explain relatively well debt policy in SMEs, although the underlying justification of this theory in our case may resemble manager's propensity to not losing part of their control in the firm. Put another way, SMEs rely their financing on internal resources instead of turning to outside the firm.

Regarding to future lines of research on SMEs capital structure, the study will improve considering a broader time period analysis in order to elucidate whether capital structure in this sort of companies changes along different economic cycles. Furthermore, the analysis could be enriched by taking a dynamical look to the issue and formulating dynamic models of debt policy with instrumental variables. 


\section{REFERENCES}

Ang, James S. (1991): "Small business uniqueness and the theory of financial management". The Journal of Small Business Finance, 1 (1), pp. 1-13.

Ang, James S. (1992): "On the theory of finance for privately held firms". The Journal of Small Business Finance, 1 (3), pp. 185-203.

Ang, James S.; Chua, Jess H. and McConnell, John J. (1982): "The administrative costs of corporate bankruptcy: a note". The Journal of Finance, vol. XXXVII, $\mathrm{n}^{\circ}$ 1, March, pp. 219-226.

Arellano, Manuel y Bover, Olympia (1990): "La econometría de datos de panel". Investigaciones Económicas, vol. XIV, nº 1, pp. 3-45.

Auberbach, A.J. (1985): "Real determinants of corporate leverage". En Benjamin M. Friedman (ed.), 1.985, Corporate capital structures in the United States, University of Chicago Press, Chicago, pp. 301-322.

Aybar Arias, Cristina; Casino Martínez, Alejandro y López Gracia, José (1999): "Los determinantes de la estructura de capital de la pequeña y mediana empresa". Paper presented at the VII Workshop in Finance, November, Valencia.

Aybar Arias, Cristina; Casino Martínez, Alejandro y López Gracia, José (2000): “Enfoques emergentes en torno a la estructura de capital: el caso de la Pyme". Paper presented at the VIII Workshop in Finance, October, Madrid.

Azofra Palenzuela, Valentín and Fernández Álvarez, Ana Isabel (1999): "Las finanzas empresariales 40 años después de las proposiciones de MM. Teorías y realidades". Papeles de Economía Española, n 78-79, pp. 122-144.

Baltagi, Badi H. (1995): "Econometric Analysis of Panel Data". John Wiley \& Sons.

Barclay, Michael J.; Smith, Clifford W. and Watts, Ross L. (1995): "The determinants of corporate leverage and dividend policies". Journal of Applied Corporate Finance, Vol. 7, n 4, Winter, pp. 4-19.

Barclay, Michael J. and Smith, Clifford W. Jr. (1999): "The capital structure puzzle: another look at the evidence". Journal of Applied Corporate Finance, Spring, vol. 12, n 1, pp. 8-20.

Bevan, Alan A. and Danbolt, Jo (2000a): "Capital structure and its determinants in the United Kingdom - A decompositional analysis". Mimeo, 2000/2, Department of Accounting and Finance, University of Glasgow.

Bevan, Alan A. and Danbolt, Jo (2000b): "Dynamics in the determinants of capital structure in the UK". Mimeo, 2000/9, Department of Accounting and Finance, University of Glasgow.

Boedo Vilabella, Lucía and Calvo Silvosa, Anxo Ramón (1997): "Un modelo de síntesis de los factores que determinan la estructura de capital óptima de las PYMES". Revista Europea de Dirección y Economía de la Empresa, vol. 6, n 1, pp. 107-124. 
Bradley, Michael; Jarrell, Gregg A. and Kim, E. Han (1984): "On the existence of an optimal capital structure: theory and evidence". The Journal of Finance, vol. XXXIX, n 3, July, pp. 857-878.

Brealey, Richard A. and Myers, Stewart C. (2000): "Principles of corporate finance", $6^{\text {th }}$ edition. McGraw - Hill.

Calcagnini, Giorgio and lacobucci, Donato (1997): "Small firm investment and financing decisions: an option value approach". Small Business Economics, 9, pp. 491-502.

Calvo, José L. and Lorenzo, María José (1993): "La estructura financiera de las PME manufactureras españolas". Economía Industrial, Septiembre - Octubre, pp. 3744.

Chen, Linda H.; Lensink, Robert and Sterken, Elmer (1998): "The determinants of capital structure: evidence from Dutch panel data". Paper presented at the European Economic Association Annual Congress, September 2 - 5, Berlin.

Chittenden, Francis; Hall, Graham and Hutchinson, Patrick (1996): "Small firm growth, access to capital markets and financial structure: review of issues and an empirical investigation". Small Business Economics, 8, pp. 59-67.

Constand, Richard L.; Osteryoung, Jerome S. and Nast, Donald A. (1989): "Asset - Based financing and the determinants of capital structure in the small firm". En Rassoul Yazdipour (ed.), "Advances in Small Business Finance", 1.991, pp. 29-45, Kluwer Academic Publishers.

DeAngelo, Harry and Masulis, Ronald W. (1980): "Optimal capital structure under corporate and personal taxation". Journal of Financial Economics, 8, pp. 3-29.

Eurostat (1996): "Enterprises in Europe". Fourth Report.

Friend, Irwin and Hasbrouck, Joel (1988): "Determinants of capital structure". In Andy Chen (ed.), Research in Finance, vol. 7, JAl Press Inc., New York, pp. 1-19.

Graham, John R. (1996): "Debt and the marginal tax rate". Journal of Financial Economics, 41, May, pp. 41-73.

Hamilton, R.T. and Fox, M.A. (1998): "The financing preferences of small firm owners". International Journal of Entrepreneurial Behaviour \& Research, vol. 4, $n^{\circ} 3$, pp. 239-248.

Harris, Milton and Raviv, Artur (1990): "Capital structure and the informational role of debt". The Journal of Finance, vol. XLV, n² 2, June, pp. 321-349.

Harris, Milton and Raviv, Artur (1991): "The theory of capital structure". The Journal of Finance, vol. XLVI, $n^{\circ} 1$, March, pp. 297-355.

Hausman, J.A. (1978): "Specification tests in econometrics". Econometrica, 46, pp. 1251 1271. 
Holmes, Scott and Kent, Pam (1991): "An empirical analysis of the financial structure of small and large australian manufacturing enterprises". The Journal of Small Business Finance, 1 (2), pp. 141-154.

Jordan, Judith; Lowe, Julian and Taylor, Peter (1998): "Strategy and financial policy in UK small firms". Journal of Business Finance \& Accounting, 25 (1) \& (2), January/March, pp. 1-27.

López Gracia, José and Aybar Arias, Cristina (2000): "An empirical approach to the financial behaviour of small and medium sized companies". Small Business Economics, 14, pp. 55-63.

López Gracia, José; Riaño Donnay, Vicente and Romero Martínez, Mariano (1999): "Restricciones financieras y crecimiento: el caso de la Pyme valenciana". Revista Española de Financiación y Contabilidad, vol. XXVIII, nº 99, Enero - Marzo, pp. 349-382.

Maroto Acín, Juan Antonio (1996): "Estructura financiera y crecimiento de las Pymes". Economía Industrial, n³10, IV, 29-40.

Mato, Gonzalo (1990): "Un análisis econométrico de la política de endeudamiento de las empresas con datos de panel". Investigaciones Económicas, vol. XIV, nº 1, pp. 6383.

Michaelas, Nicos; Chittenden, Francis and Poutziouris, Pannikos (1999): "Financial policy and capital structure choice in UK SMEs: empirical evidence from company panel data". Small Business Economics, 12, pp. 113-130.

Modigliani, Franco and Miller, Merton H. (1958): "The cost of capital, corporation finance and the theory of investment". The American Economic Review, vol. 68, n 3, Junio, pp. 261-297.

Modigliani, Franco and Miller, Merton H. (1963): "Corporate income taxes and the cost of capital: a correction". The American Economic Review, vol. 53, n² 2, Junio, pp. 433-443.

Myers, Stewart C. (1977): "Determinants of corporate borrowing". Journal of Financial Economics, 5, pp. 147-175.

Myers, Stewart C. (1984): "The capital structure puzzle". The Journal of Finance, vol. XXXIX, $n^{\circ}$ 3, July, pp. 575-592.

Myers, Stewart C. and Majluf, Nicholas S. (1984): "Corporate financing and investment decisions when firms have information that investors do not have". Journal of Financial Economics, 13, pp. 187-221.

Ocaña, Carlos; Salas, Vicente and Vallés, Javier (1994): "Un análisis empírico de la financiación de la pequeña y mediana empresa manufacturera española: 1.9831.989". Moneda y Crédito, n 199, pp. 57-96.

Opler, Tim and Titman, Sheridan (1996): "The debt - equity choice". Unpublished working paper, Boston College, Boston, MA. 
Pettit, R. and Singer, R. (1985): "Small business finance: a research agenda". Financial Management, vol. 14, n 3, Autumn, pp. 47-60.

Rajan, Raghuram G. and Zingales, Luigi (1995): "What do we know about capital structure? Some evidence from international data". The Journal of Finance, vol. L, $n^{\circ}$ 5, December, pp. 1.421-1.460.

Ryen, Glen T.; Vasconcellos, Geraldo M. and Kish, Richard J. (1997): "Capital structure decisions: What have we learned?". Business Horizons, September - October, pp. 41-50.

Sáez Fernández, Francisco Javier (1996): "La financiación de la pyme española: evidencia empírica para el período 1.991-1.994". Cuadernos de Información Económica, n 109, Abril, pp. 78-86.

Scott, James H. Jr. (1976): "A theory of optimal capital structure". The Bell Journal of Economics, 34, Spring, pp. 33-54.

Scott, James H. Jr. (1977): "Bankruptcy, secured debt, and optimal capital structure". The Journal of Finance, XXXII, March, pp. 1-19.

Shyam - Sunder, Lakshmi and Myers, Stewart C. (1999): "Testing static tradeoff against pecking order models of capital structure". Journal of Financial Economics, 51, pp. 219-244.

Smith, Clifford and Warner, Jerold (1979): "On financial contracting: an analysis of bond covenants". Journal of Financial Economics, 7, n² 2, June, pp. 117-161.

Titman, Sheridan and Wessels, Roberto (1988): "The determinants of capital structure choice". The Journal of Finance, vol. XLIII, n 1, March, pp. 1-19.

Van der Wijst, D. (1989): "Financial structure in small business. Theory, tests and applications". Lecture notes in economics and mathematical systems, $n^{\circ} 320$, Springer - Verlag.

Van der Wijst, Nico (1997): "Firm Finance and Growth: an empirical analysis". In Constantin Zopounidis (ed.), New Operational Approaches for Financial Modelling, Physica - Verlag, pp. 209-220.

Van der Wiist, N. and Thurik, R. (1993): "Determinants of small firm debt ratios: an analysis of retail panel data". Small Business Economics, 5, pp. 55-65.

Wald, John K. (1999): "How firm characteristics affect capital structure: an international comparison". The Journal of Financial Research, vol. XXII, n² 2, Summer, pp. 161 187.

Walker, David A. (1989a): "Financing the small firm". Small Business Economics, 1, Fall, pp. 285-296.

Walker, David A. (1989b): "An empirical analysis of financing the small firm". In Rassoul Yazdipour (ed.), "Advances in Small Business Finance", 1.991, pp. 47-61, Kluwer Academic Publishers. 
Warner, Jerold B. (1977): "Bankruptcy costs: some evidence". The Journal of Finance, vol. XXXII, n², May, pp. 337-347.

Wiwattanakantang, Yupana (1999): "An empirical study on the determinants of the capital structure of Thai firms". Pacific - Basin Finance Journal, 7, pp. 371-403. 


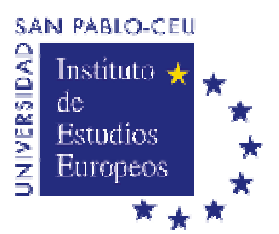

POLO EUROPEO JEAN MONNET

JeAn Monnet European Centre of EXCEllence

\section{BOLETÍN DE SUSCRIPCIÓN}

Deseo recibir gratuitamente los dos próximos números de la Colección de informes del

Observatorio de Economía Europea del Instituto de Estudios Europeos

de la Universidad San Pablo-CEU

Nombre y Apellidos.

Dirección

Población.

C.P

País.

Teléfono.

Correo electrónico.

Instituto de Estudios Europeos

Universidad San Pablo-CEU

Julián Romea, 22 - 28003 Madrid

Tfno: 915140422

Fax: 915140428

E-mail: idee@ceu.es

www.ceu.es/idee 


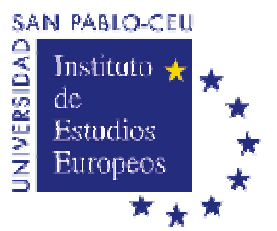

POLO EUROPEO JEAN MONNET

JEAN MONNET EuROPEAN CENTRE OF EXCELLENCE

\section{PETICIÓN DE NÚMEROS ATRASADOS}

Nombre y Apellidos

Dirección.

Población.

C.P

País.

Teléfono

Correo electrónico.

Deseo recibir los siguientes números de la Colección de Informes del Observatorio de Economía Europea del Instituto de Estudios Europeos de la Universidad San Pablo-CEU $\mathrm{N}^{\mathrm{O}}$

Títulos.

Instituto de Estudios Europeos

Universidad San Pablo-CEU

Julián Romea, 22 - 28003 Madrid

Tfno: 915140422

Fax: 915140428

E-mail: idee@ceu.es

www.ceu.es/idee 


\section{NÚMEROS PUBLICADOS}

N 1 - 2002 Análisis de la financiación de los fondos estructurales en el ámbito de la política regional de la Unión Europea durante el período 1994-1999 


\title{
CONSEJO ASESOR
}

\section{INSTITUTO DE ESTUDIOS EUROPEOS}

\author{
Íñigo Cavero Lataillade, Presidente \\ Esperanza Aguirre Gil de Biedma \\ Fernando Alvarez de Miranda \\ Joachim Bitterlich \\ Juan Antonio Carrillo Salcedo \\ Guillermo de la Dehesa \\ Francisco Fonseca Morillo \\ Eduardo García de Enterría \\ Pablo Isla \\ José Luis Leal Maldonado \\ Araceli Mangas Martín \\ Manuel Pizarro \\ Matías Rodríguez Inciarte \\ Juan Rosell Lastortras \\ Philippe de Schoutheete de Tervarent \\ José Vidal Beneyto \\ Xavier Vidal Folch \\ Gustavo Villapalos
}

\section{INSTITUTO DE ESTUDIOS EUROPEOS}

\author{
Presidente \\ Marcelino Oreja Aguirre \\ Director \\ José María Beneyto Pérez \\ Secretario \\ Francisco Conde López
}




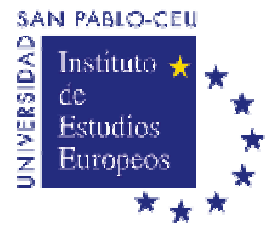

POLO EUROPEO JEAN MONNET

JEAN MONNET EurOPEAN CeNTRE Of EXCELleNCE 